\title{
PERMAINAN TRADISIONAL KAULINAN BARUDAK UNTUK MENGEMBANGKAN SIKAP EMPATI DAN POLA GERAK DASAR ANAK USIA DINI
}

\author{
Lutfi Nur $^{1}$, Momoh Halimah ${ }^{2}$, Istikhoroh Nurzaman ${ }^{3}$ \\ ${ }^{1}$ Program Studi PGPAUD UPI Kampus Tasikmalaya \\ ${ }^{2}$ Program Studi PGSD UPI Kampus Tasikmalaya \\ ${ }^{3}$ Program Studi PGPAUD UPI Kampus Tasikmalaya
}

Email: lutfinur@upi.edu

(Received: September 2017; Accepted: Oktober 2017; Published: Desember 2017)

\begin{abstract}
This research is based on the facts in the field regarding the process of achieving early childhood education that is not optimal. Eeducational attainment is about to manage sel emotion of early childhood. The traditional games "kaulinan barudak" are one of the learning process approaches could be expected to provide positive stimulation toward developmental aspect of children's potential. This study is conducted to determine the contribution of traditional games "kaulinan barudak" to the development of self emotion manage of children aged 5-6 years. This study uses quasi-experimental method with Pretest and Posttest control group design. Data is collected using structured observation, notes, and documentation. The results of this study are 1) the ability of self emotion manage of children aged 5-6 years in kindergarten Artanita Tasikmalaya entered into category"positive significant"; 2) the ability of self emotion manage of children aged 5-6 years of conventional game in kindergarten Artanita Tasikmalaya entered into category"no siginificant positive effect"; 3) the ability of self emotion manage of children aged 5-6 years in kindergarten Artanita Tasikmalaya entered into category"Different effect of traditional game "kaulinan barudak" from the conventional game". The traditional game of "kaulinan barudak" gives a more significant positive effect than the conventional game.
\end{abstract}

Keywords: Traditional Games "Kaulinan Barudak", Empathy Attitude, Basic Motion Pattern of Early Childhood

\begin{abstract}
ABSTRAK
Penelitian ini dilatarbelakangi oleh fakta-fakta di lapangan mengenai kondisi proses pencapaian pendidikan anak usia dini yang belum optimal. Proses pencapaian pendidikan yang dimaksud adalah sikap empati dan pola gerak dasar anak usia dini. Permainan tradisional "kaulinan barudak" merupakan salah satu pendekatan proses belajar yang diduga dapat memberikan stimulasi positif terhadap aspek perkembangan potensi anak. Penelitian ini dilakukan untuk mengetahui kontribusi permainan tradisional "kaulinan barudak" terhadap pengembangan sikap empati dan pola gerak dasar anak usia 5-6 tahun. Penelitian ini menggunakan metode kuasi eksperimen dengan Pretest-Posttest control group design. Subjek siswa yang akan dilibatkan adalah anak usia dini di TK Perwari dan RA Istiqomah, dan jumlah sampel dalam penelitian ini sebanyak 17 orang sesuai jumlah di TK Perwari dan RA Istiqomah. Instrumen dalam penelitian ini menggunakan observasi terstruktur, catatan lapangan, dan dokumentasi. Hasil penelitian ini 1) profil kemampuan bersikap empati dan pola gerak dasar anak usia 5-6 tahun di TK Perwari Kota Tasikmalaya dan RA Istiqomah Kota Tasikmalaya masuk ke dalam kategori "Muncul", 2) program kegiatan pembelajaran meningkat, 3) program kegiatan pembelajaran dengan permainan konvensional menunjukan cukup baik, 4) kemampuan pola gerak dasar pada kelompok eksperimen meningkat.; 5) profil sikap empati dan pola gerak dasar setelah melalui penerapan permainan konvensional meningkat, 6) terdapat perbedaan yang signifikan antara sikap empati dan pola gerak dasar di kelompok kontrol dan eksperimen.
\end{abstract}

Kata Kunci : Permainan Tradisional "Kaulinan Barudak", Sikap Empati, Pola Gerak Dasar Anak Usia Dini 


\section{PENDAHULUAN}

Pendidikan anak usia dini merupakan hal penting dan dipandang perlu untuk diketahui oleh setiap guru maupun orang tua yang mendidik anak tersebut. Secara tidak langsung dalam konteks ini tersirat tanggung jawab moral bagi guru di sekolah maupun orang tua di rumah untuk memahami nilai-nilai pendidikan yang harus dikembangkan oleh orang tua, guru dan lingkungan sekitarnya. Untuk memahami karakteristik anak, guru dan orang tua harus melakukan pemantauan secara khusus dan intensif terhadap segala bentuk perilaku anak yang muncul saat melakukan aktivitas di sekolah maupun di rumah. Melalui proses pemantauan secara khusus tersebut, maka akan didapat data-data berupa capaian perkembangan pendidikan anak. Data-data yang didapat dari hasil pemantauan terhadap capaian perkembangan anak tersebut dapat dijadikan sebagai tolak ukur untuk pemenuhan kebutuhan anak itu sendiri.

Perkembangan setiap karakteristik anak usia dini cenderung dipengaruhi oleh sentuhansentuhan secara fisik maupun psikis dari lingkungan hidupnya. Konteks itu dikuatkan oleh Geldard \& Geldard (2012) bahwa lingkungan merupakan bagian terbesar dalam mempengaruhi perubahan perilaku setiap anak. Hal tersebut terjadi karena lingkungan hidup cenderung lebih menyentuh setiap aspek perkembangan anak secara dominan.Berdasarkan teori tersebut, dapat diartikan bahwa lingkungan merupakan aspek terbesar dan dapat memberikan pengaruh terhadap perkembangan anak. Lingkungan pendidikan secara formal sering dinyatakan dengan istilah sekolah. Sekolah merupakan salah satu bagian dari lingkungan hidup anak untuk mengeksplorasikan setiap potensi yang dimilikinya.

Berdasarkan hasil studi lapangan, bahwa terdapat beberapa hal yang dapat dinyatakan sebagai persoalan yang berkaitan dengan pencapaian proses pendidikan anak usia dini, antara lain yaitu sikap empati dan pola gerak dasar yang kesemuanya itu merupakan kompetensi dasar yang diharapkan dimiliki anak agar kedepannya mereka lebih siap melanjutkan pendidikan ke jenjang berikutnya serta dapat menjalani kehidupannya dengan cenderung lebih baik.

Penerapan sikap empati dan pola gerak dasar anak usia yang terjadi di lapangan masih belum optimal, juga persoalan lain terkait stimulus guru dalam memfasilitasi kegiatan terlihat belum berani melakukan penerapan pendekatan secara khusus di sekolah untuk mengembangkan sikap empati dan pola gerak dasar khususnya pada anak usia 5-6 tahun.

Pendidikan karakter dan pengembangan pola gerak dasar sebaiknya diterapkan sejak anak usia dini karena sangat menentukan kemampuan anak dalam mengembangkan potensinya, lebih lanjut lagi merupakan bekal penting dalam mempersiapkan anak usia dini untuk menyongsong masa depan yang penuh dengan tantangan, baik secara akademis maupun dalam kehidupan berbangsa dan bernegara (Sudaryanti, 2012).

Sekaitan dengan pengembangan anak usia dini, David W.J, etc (2009), menyatakan hasil penelitiannya bahwa perkembangan kognitif anak usia dini terkait berbagai faktor yang mempengaruhinya antara lain faktor sosial ekonomi, seperti pendidikan, penghasilan orang tua, profesi pekerjaan. Artinya pengembangan aspek lainnya seperti sikap empati dan pola gerak dasar memiliki kecenderungan bahwa pada anak usia dini merupakan waktu yang paling efektif untuk dilakukan hal tersebut.

Anak usia dini cenderung lebih dekat dengan dunia bermain. Gandana (2015) dalam penelitiannya mengugkap bahwa permainan tradisional merupakan metode yang tepat dan dapat diterapkan untuk anak usia 5-6 tahun. Oleh karena itu permainan Tradisioanal "Kaulinan Barudak" merupakan salah satu bentuk permainan yang dapat diterapkan dan dijadikan sebagai metode khusus yang diduga dapat mengembangkan sikap empati dan pola gerak dasar anak usia 5-6 tahun.

Kecenderungan-kecenderungan tersebut menggugah pola pikir peneliti bahwa betapa pentingnya penanaman dan pengembangan sikap empati dan pola gerak dasar anak usia 
dini melalui lingkungan alam secara nyata. Kemudian dikaitkan dengan peran permainan tradisional "kaulinan barudak" yang cenderung terdapat unsur-unsur stimulus terhadap setiap aspek perkembangan anak. Maka, salah satu solusi berupa metode khusus untuk mengembangkan potensi anak usia dini adalah diterapkannya permainan tradisional "Kaulinan Barudak" dalam upaya mengoptimalkan proses pencapaian pendidikan di sekolah. Asumsinya bahwa Kemampuan bersikap empati dan pola gerak dasar dapat ditingkatkan melalui penerapan permainan tradisional kaulinan barudak.

\section{TINJAUAN PUSTAKA}

Kemampuan anak dalam bersikap empati kecenderungan dapat dilihat dari kemampuan anak dalam merasakan perasaan orang lain dan kemampuan menyatukan hati dengan orang lain (Mashar, 2011; Geldard \& Geldard, 2012; dan Yusuf, 2012). Anak mampu merasakan perasaan orang lain berarti anak itu memiliki perasaan peka atau sensitif dan dapat memahami perspektif atau pandangan orang lain. Kemampuan tersebut dapat ditunjukan oleh sikap anak dalam berperilaku mau mendengarkan informasi yang disampaikan orang lain dengan fokus, mampu memperhatikan pendapat temannya dengan serius, memberikan pertolongan ataupun bantuan kepada temannya dengan mengulurkan tangan sataupun meminjamkan alat belajar kepada temannya, memberikan perlindungan kepada temannya dari ancaman yang berbahaya, mau melayani temannya bermain, tidak mengganggu temannya belajar, rela mengorbankan waktu bermainnya untuk orag lain, maupun mengambilkan barang temannya yang terjatuh.

Kemudian Beaty (1994) dan Sujanto, dkk, (2009) berpendapat bahwa kemampuan anak dalam menyatukan hati dengan orang lain yakni didalamnya terdapat hal yang harus dikuasai oleh anak antara lain mampu menyatukan perasaan, mampu menyatukan persepsi dengan teman maupun gurunya, dan mampu mengemukakan rasa cinta dan kasih sayang kepada temannya. Ekspresi emosi tertebut cenderung dapat dilihat dari perilaku anak saling menepukan telapak tangannya, memberikan semangat kepada orang lain, mengucapkan selamat kepada orang lain yang berhasi lmelakukan diskusi untuk menyamakan persepsi sebelum melakukan kegiatan, dan menyapakati aturan yang telah disepakati bersama. (Ioannidou \& Konstantikaki, 2008; Ruiz, dkk, 2010; Mashar, 2011).

Perkembangan gerak dasar dan penyempurnaannya merupakan hal penting di masa kanak-kanak. Semua anak normal mampu mengembangkan dan mempelajari berbagai macam gerak dan yang lebih rumit. Gerakan-gerakan dasar merupakan gerak pengulangan yang dilakukan terus menerus dari kebiasaan serta menjadikannya sebagai dasar dari pengalaman dan lingkungan mereka.

Bambang Sujiono (2009: 5.3) menjelaskan bahwa pengembangan gerak dasar adalah proses di mana anak memperoleh gerak dasar yang senantiasa berkembang berdasarkan: proses pengembangan syaraf dan otot yang juga dipengaruhi oleh keturunan, akibat dari pengalaman gerak sebelumnya, Pengalaman gerak saat ini; dan gerak yang digambarkan dalam kaitannya dengan pola gerak tertentu.

Malina, Dauer dan Pangrazi serta Kogan (Mahendra, 2007: 18) menjelaskan mengenai pola gerak dasar dibagi ke dalam 3 bentuk gerak sebagai berikut: 1) Gerak lokomotor adalah gerakan yang menyebabkan terjadinya perpindahan tempat atau keterampilan yang digunakan memindahkan tubuh dari satu tempat ke tempat lainnya. Misalnya gerakan berjalan, berlari, melompat dan lain-lain, 2) Gerak nonlokomotor adalah gerakan yang tidak menyebabkan pelakunya berpindah tempat, seperti menekuk, membungkuk, mengayun, melenting, mendorong, menarik dan lain-lain, 3) Gerak manipulatif adalah gerakan yang mempermainkan obyek tertentu sebagai medianya, atau keterampilan melibatkan kemampuan seseorang dalam menggunakan bagian-bagian tubuhnya untuk memanipulasi benda di luar dirinya. misalnya melempar, menangkap, menyepak, memukul, 
dan gerakan lain yang berkaitan dengan lemparan dan tangkapan sesuatu.

\section{METODE}

Metode penelitian yang digunakan dalam penelitian ini adalah metode eksperimen, desain penelitian yang digunakan dalam penelitian ini adalah Quasi Eksperimen dengan bentuk Nonequivalent Pretest-Posttest Control Group Design. Hal tersebut merujuk kepada Creswell (2010, hlm 132) bahwa penelitian ini akan melakukan Pretest dan Posttest terhadap dua PAUD; yaitu TK Perwari dan RA Istiqomah untuk dilihat hal dalam pembelajarannya.

\begin{tabular}{cccc}
$\begin{array}{c}\text { Kelom } \\
\text { pok }\end{array}$ & $\begin{array}{c}\text { Pre } \\
\text { test }\end{array}$ & $\begin{array}{c}\text { Perlak } \\
\text { uan }\end{array}$ & $\begin{array}{c}\text { Post } \\
\text { test }\end{array}$ \\
\hline $\begin{array}{c}\text { Eksperi } \\
\text { men }\end{array}$ & $\mathrm{O} 1$ & $\mathrm{X}$ & $\mathrm{O} 2$ \\
Kontrol & $\mathrm{O} 3$ & - & $\mathrm{O} 4$ \\
\hline
\end{tabular}

Subjek yang akan dilibatkan adalah anak usia 5-6 tahun TK Perwari dan RA Istiqomah Jumlah sampel dalam penelitian ini sebanyak 15 anak di kelompok B TK Perwari dan 15 anak di RA Istiqomah. Instrumen yang digunakan dalam penelitian ini yaitu 1) observasi terstruktur; 2) catatan lapangan; dan 3) dokumentasi tentang sikap empati dan pola gerak dasar. Penggunaan instrumen ini berlandas kepada Sugiyono (2012) terkait beberapa instrumen yang cenderung tepat digunakan sebagai alat untuk pengambilan data dalam penelitian ini adalah pedoman observasi terstruktur, catatan lapangan, dan dokumentasi. Karena, tiga instrumen tersebut dipandang cukup dan dapat memberikan kontribusi dalam mendapatkan data-data untuk melihat perkembangan sikap empati dan pola gerak dasar anak usia 5-6 tahun

\section{HASIL DAN PEMBAHASAN}

\section{Profil Sikap Empati dan Pola Gerak Dasar Awal}

Untuk dapat memberikan gambaran secara umum tentang data yang telah diperoleh dari hasil penelitian, maka data-data tersebut dianalisis membandingkan peningkatan antara kedua kelompok. Langkah pertama yang peneliti lakukan adalah melakukan tes awal atau pretest. Berikut ini peneliti menampilkan hasil pretes sikap empati pada Tabel 1 dan 2 berikut ini:

Tabel 1.Tabel Profil Pretest Sikap Empati Kelompok Kontrol

\begin{tabular}{cccccccccc}
\hline Item & IT & IT & IT & I & IT & IT & IT & IT & Ju \\
Obse & $\mathbf{1}$ & $\mathbf{2}$ & $\mathbf{3}$ & $\mathbf{T}$ & $\mathbf{5}$ & $\mathbf{6}$ & $\mathbf{7}$ & $\mathbf{8}$ & $\mathbf{m l}$ \\
rvasi & & & & $\mathbf{4}$ & & & & & $\mathbf{a h}$ \\
\hline $\begin{array}{c}\text { Juml } \\
\text { ah }\end{array}$ & 27 & 20 & 23 & 2 & 24 & 21 & 18 & 21 & $\mathbf{1 8 1}$ \\
Rata & 1, & 1, & 1, & 1, & 1, & 1, & 1, & 1, & $\mathbf{1 0}$ \\
-rata & 59 & 18 & 35 & 5 & 41 & 24 & 06 & 24 & $\mathbf{6 5}$ \\
& & & & 9 & & & & & \\
Simp & 0, & 0, & 0, & 0, & 0, & 0, & 0, & 0, & $\mathbf{1 , 8}$ \\
anga & 71 & 39 & 49 & 5 & 62 & 44 & 24 & 44 & $\mathbf{7}$ \\
n & & & & 1 & & & & & \\
Baku & & & & & & & & & \\
Prese & 52 & 39 & 45 & 5 & 47 & 41 & 35 & 41 & $\mathbf{4 4 ,}$ \\
ntase &, 9 &, 2 &, 1 & 2, &, 0 &, 1 &, 2 &, 1 & $\mathbf{3 6}$ \\
$(\%)$ & 4 & 2 & 0 & 9 & 6 & 8 & 9 & 8 & \\
\hline
\end{tabular}

Pada Tabel 1 diatas menujukan data pretest sikap empati pada kelompok kontrol. Dengan jumlah sampel 17 anak, dan 8 item observasi, diperoleh jumlah skor terendah 18 dan jumlah skor tertinggi 27. Rata-rata skor dengan rentan 1,06 sampai 1,59. Berdasarkan kategori item observasi dengan rata-rata nilai tertinggi 1,59 masuk kedalam kategori "Muncul", dapat diartikan rata-rata sikap empati pada anak usia 5-6 tahun pada kelompok kontrol hanya baru terlihat beberapa kali saja, atau belum sering terlihat dilakukan oleh anak. Berdasarkan presentase dengan presentase terendah $35,29 \%$ dan presentase tertinggi 52,94\%. Sedangkan untuk data pretest sikap empati pada kelompok eksperimen dapat dilihat pada Tabel 2 berikut ini: 
Tabel 2.Tabel Profil Pretest Sikap Empati Kelompok Eksperimen

\begin{tabular}{|c|c|c|c|c|c|c|c|c|c|}
\hline Item & I & I & I & I & I & IT & I & I & $\mathbf{J u}$ \\
\hline Obs & $\mathbf{T}$ & $\mathbf{T}$ & $\mathbf{T}$ & $\mathbf{T}$ & $\mathbf{T}$ & 6 & $\mathbf{T}$ & $\mathbf{T}$ & ml \\
\hline $\begin{array}{c}\text { erva } \\
\text { si }\end{array}$ & 1 & 2 & 3 & 4 & 5 & & 7 & 8 & ah \\
\hline Jum & 1 & 1 & 1 & 2 & 2 & 1 & 1 & 1 & 15 \\
\hline lah & 9 & 9 & 8 & 3 & 0 & 8 & 8 & 7 & 2 \\
\hline Rata & 1, & 1, & 1, & 1, & 1, & 1, & 1, & 1, & 8,9 \\
\hline - & 1 & 1 & 0 & 3 & 1 & 0 & 0 & 0 & 4 \\
\hline rata & 2 & 2 & 6 & 5 & 8 & 6 & 6 & 0 & \\
\hline Sim & 0 & 0 , & 0 , & 0 , & 0 , & 0 , & 0 , & 0 , & 1,2 \\
\hline pan & 3 & 3 & 2 & 4 & 3 & 2 & 2 & 0 & 0 \\
\hline gan & 3 & 3 & 4 & 9 & 9 & 4 & 4 & 0 & \\
\hline $\begin{array}{c}\text { Bak } \\
\mathbf{u}\end{array}$ & & & & & & & & & \\
\hline Pres & 3 & 3 & 3 & 4 & 3 & 3 & 3 & 3 & 37, \\
\hline enta & 7 & 7, & 5, & 5, & 9, & 5, & 5, & 3 , & 25 \\
\hline se & 2 & 2 & 2 & 1 & 2 & 2 & 2 & 3 & \\
\hline$(\%)$ & 5 & 5 & 9 & 0 & 2 & 9 & 9 & 3 & \\
\hline
\end{tabular}
pretest sikap empati pada kelompok eksperimen. Berdasarkan data yang diperoleh terdapat jumlah skor terendah 17 dan jumlah skor tertinggi 23. Rata-rata skor dengan rentan 1,00 sampai 1,35. Berdasarkan kategori item observasi dengan rata-rata nilai tertinggi 1,35 masuk kedalam kategori "Muncul", dapat diartikan rata-rata sikap empati pada anak usia 5-6 tahun pada kelompok eksperimen hanya baru terlihat beberapa kali saja, atau belum sering terlihat dilakukan oleh anak. Berdasarkan presentase dengan presentase terendah $33,33 \%$ dan presentase tertinggi 45,10\%. Berdasarkan Tabel 4.1. dan 4.2. dapat dilihat bahwa kelompok kontrol menunjukan pencapaian skor yang lebih tinggi dari pada kelompok eksperimen.

Setelah menunjukan profil data kemampuan sikap emapati, selanjutnya peneliti menyajikan profil data pretes kemampuan pola gerak dasar anak usia 5-6 tahun pada tabel 3 dan 4 sebagai berikut:
Tabel 3.Tabel Profil Pretest Pola Gerak Dasar Kelompok Kontrol

\begin{tabular}{ccc}
\hline & Pencapaian & $\begin{array}{c}\text { Jumlah } \\
\text { Skor } \\
\text { Sempurna }\end{array}$ \\
\hline Jumlah Skor & 1156 & 1904 \\
Rata-rata & 68 & 112 \\
Simpangan & 4,39 & 0 \\
Baku & & 100 \\
$\begin{array}{c}\text { Presentase } \\
(\%)\end{array}$ & 60,71 & \\
\hline
\end{tabular}

Item observasi pada variabel pola gerak dasar berjumlah 28 item, oleh karena itu dalam pembahasan ini peneliti tidak bisa menampilkan profil data peritem observasi. Pada Tabel 4.3. tersebut jumlah skor 1156 dari skor sempurna 1904. Rata-rata skor 68 dari rata-rata skor sempurna 112 . Sedangkan secara keseluruhan kemampuan pola gerak dasar diperoleh presentase pencapaian sebesar $60,71 \%$. Untuk profil data pretes pada kelompok kontrol dapat dilihat pada Tabel 4 berikut ini:

Tabel 4.Tabel Profil Pretest Pola Gerak Dasar Kelompok Eksperimen

\begin{tabular}{ccc}
\hline & Pencapaian & $\begin{array}{c}\text { Jumlah } \\
\text { Skor } \\
\text { Sempurna }\end{array}$ \\
\hline Jumlah Skor & 1158 & 1904 \\
Rata-rata & 68,12 & 112 \\
Simpangan & 3,87 & 0 \\
Baku & & 100 \\
Presentase & 60,81 & \\
$(\%)$ & &
\end{tabular}

Tabel 3 diatas menunjukan jumlah skor 1158 dari skor sempurna 1904. Rata-rata skor 68,12 dari rata-rata skor sempurna 112. Sedangkan secara keseluruhan kemampuan pola gerak dasar pada kelompok eksperimen diperoleh presentase pencapaian sebesar 60,81\%. Berdasarkan kedua Tabel 3 dan 4 menunjukan bahwa secara keseluruhan data pretest dari kedua kelompok sampel tidak jauh berbeda, hanya berbeda beberapa digit skor saja. 


\section{Program Kegiatan Pembelajaran Melalui Penerapan Permainan Tradisional "Kaulinan Barudak"}

Permainan tradisional "kaulinan barudak" merupakan suatu kumpulan permainan yang diwariskan turun temurun dari generasi ke generasi. Dalam permainan ini terdapat berbagai nilai, seperti nilai tradisi, budaya, dan juga permainan aktif yang bermanfaat bagi perkembangan anak. Menurut Bishop \& Curtis dalam Iswinarti (2010, hlm 6) mengemukakan bahwa "Permainan tradisional merupakan suatu permainan yang telah dilakukan atau dimainkan oleh anak-anak pada suatu daerah tertentu secara tradisi dan permainan tersebut telah diwariskan dari generasi ke generasi untuk meneruskan tradisi daerah tersebut." Permainan tradisional bermunculan dari berbagai daerah dan tersebar seiring dengan perkembangan jaman.

Berbagai Permainan tradisional "kaulinan barudak" yang diterapkan dalam pembelajaran untuk meningkatkan sikap empati dan kemampuan pola gerak dasar anak usia 5-6 tahun pada kelas eksperimen TK Perwari Kota Tasikmalaya adalah Sondah, Congklak, Loncat tinggi, Balap kelereng dalam sendok, Memasukan pensil pada lubang botol, Egrang Batok, Dam-Daman. Penerapan Berbagai Permainan tradisional "kaulinan barudak" pada pembelajaran tersebut dilakukan selama 2 bulan dalam total 16 kali pertemuan. Dalam setiap pertemuan anak-anak diberikan pembelajaran melalui salah satu permainan tradisional "kaulinan barudak". Dari permainan-permainan yang diterapkan dapat bagi menjadi permainan yang dominan fisik dan dominan kognitif. Permainan dominan fisik seperti Sondah, Loncat tinggi, Balap kelereng, Memasukan pensil ke botol dan egrang batok. Sedangkan permainan tradisional yang dominan kognitif adalah congklak dan dam-daman.

Pada pertemuan awal sebagaian anak masih terlihat bingung dengan permainan tradisional "kaulinan barudak" yang diberikan. Akan tetapi sebagian anak lainnya terlihat sangat antusias untuk mengikuti permainan walaupun secara keseluruhan mereka belum benar-benar mengerti permainannya. Setelah beberapa waktu hampir keseluruhan anak dapat mengikuti permainan dengan cukup baik, mampu menerapkan peraturan dan berusaha untuk mecapai target permainan. Berdasarkan pengamatan yang dilakukan peneliti, terlihat perbedaan penampilan anak pada saat pretest, pembelajaran dan posttest. Perbedaan tersebut terlihat dari segi sikap empati dan juga pola gerak dasar. Dari segi sikap empati anak yang amat terlihat jelas sebagia besar anak dapat menunjukan sikap empatinya saat temannya mengajak untuk bermain. Anak juga dapat lebih mendengarkan atau memperhatikan temannya yag sedang berbicara atau berpendapat, selain itu juga anak berinisiatif dan mau untuk mengambilkan barang untuk orang lain (teman atau guru). Sedangkan dari segi pola gerak dasar sebagian besar anak terlihat lebih baik dalam hal berjalan maju atau mundur sambil memegang suatu benda, dan juga anak terlihat lebih mampu untuk berjalan dan atau berlari keberbagai arah (zig-zag) sambil memegang benda.

Berdasarkan observasi atau pengamatan dan juga analisis yang telah peneliti lakukan, Permainan Tradisional "Kaulinan Barudak" memberikan dampak positif bagi perkembangan anak usia 5-6 tahun khususnya pada aspek atau variabel sikap empati dan kemampuan pola gerak dasar.

\section{Program Kegiatan Pembelajaran Melalui Permainan Konvensional}

Penelitian ini membagi dua kelompok sampel, kelompok eksperimen dan kontrol. Pada kelompok eksperimen peneliti memberikan perlakuan pembelajaran melalui Permainan Tradisional "Kaulinan Barudak". Sedangkan untuk kelas kontrol peneliti menerapkan pembelajaran melalui permainan konvensional. Secara garis besar program atau penerapan yang dilakukan peneliti sama dengan penerapan pada kelas eksperimen, hanya saja permainan yang diterapkan adalah permainan konvensional. Beberapa permaian konvensional yang peneliti terapkan dilakukan dengan pembagian waktu yang sama, yakni 
selama 2 bulan dalam waktu 16 kali pertemuan.

Berbeda dengan penerapan permainan tradisional "kaulinan barudak", dalam kelas kontrol ini sebagian siswa telah banyak mengenal berbagai permainan konvensional yang diterapkan. Sehingga, tidak butuh waktu lama bagi anak untuk menyesuaikan diri dalam setiap permainan. Bahkan dalam beberapa permainan anak yang merasa mengenal permainan cenderung berusaha untuk menjelaskan permainan tersebut kepada anak lainnya. Dalam penerapan permainan konvensional ini hampir dari pertemuan awal sampai pertemuan akhir anak-anak memiliki antusias yang baik.

Berdasarkan pengamatan yang dilakukan pada kelas kontrol anak-anak dapat menunjukan perkembangan yang cukup baik dalam sikap empati dan pola gerak dasar. Dalam sikap empati anak-anak lebih antusias dalam menerima ajakan temannya, mendengarkan temannya yang sedang berbicara dan juga mau untuk meminjamkan alat permainan kepada temannya. Dalam hal pola gerak dasar anak juga menunjukan perkembangan yang baik. Diantaranya mampu berjalan dengan memegang alat degan lebih baik dan juga mampu berjalan zig-zag sambil memegang sauatu benda. Pengamatan dan analisis yang telah peneliti lakukan menunjukan bahwa penerapan permainan konvensional juga menunjukan dampak yang positif bagi perkembangan anak. Karena itu, untuk lebih lanjutnya dalam penelitian ini peneliti tidak hanya melihat perkembangan dari masing-masing kelompok sampel saja, akan tetapi juga akan melakukan analisis lebih lanjut lagi, yakni dengan melakukan perbandingan peningkatan dari kedua kelompok sampel.

\section{Profil Sikap Empati dan Pola Gerak Dasar Setelah Melalui Penerapan Permainan Tradisional "Kaulinan Barudak"}

Pada pembahasan sebelumnya peneliti telah menampilkan profil data pada tes awal atau pretes. Untuk melihat peningkatannya berikut ini peneliti menampilkan profil data posttest pada kelompok eksperimen pada Tabel 5 berikut ini:

Tabel 5.Tabel Profil Posttest Sikap Empati Kelompok Eksperimen

\begin{tabular}{cccccccccc}
\hline Item & IT & IT & IT & IT & IT & IT & IT & IT & Jumlah \\
Obse & $\mathbf{1}$ & $\mathbf{2}$ & $\mathbf{3}$ & $\mathbf{4}$ & $\mathbf{5}$ & $\mathbf{6}$ & $\mathbf{7}$ & $\mathbf{8}$ & \\
rvasi & & & & & & & & & \\
& & & & & & & & & \\
\hline Jumlah & 28 & 24 & 28 & 35 & 40 & 34 & 31 & 37 & $\mathbf{2 5 7}$ \\
& & & & & & & & & \\
Rata- & 1, & 1, & 1, & 2, & 2, & 2 & 1, & 2, & $\mathbf{1 5 , 1 2}$ \\
rata & 65 & 41 & 65 & 06 & 35 & & 82 & 18 & \\
Simpan & 0, & 0, & 0, & 0, & 0, & 0, & 0, & 0, & $\mathbf{2 , 2 0}$ \\
gan & 49 & 51 & 70 & 56 & 61 & 35 & 81 & 64 & \\
Baku & & & & & & & & & \\
& & & & & & & & & \\
Present & 54 & 47 & 54 & 68 & 78 & 66 & 60 & 72 & $\mathbf{6 2 , 9 9}$ \\
ase $(\boldsymbol{\%})$ &, 9 &, 0 &, 9 &, 6 &, 4 &, 6 &, 7 &, 5 & \\
& 0 & 6 & 0 & 3 & 3 & 7 & 8 & 5 & \\
\hline
\end{tabular}

Pada 5 diatas menujukan data posttest sikap empati pada kelompok eksperimen atau kelompok yang mendapatkan perlakuan permainan tradisional. Rentan jumlah skor antara 24 sampai 40. Sedangkan rata-rata skor dengan skor terendah 1,41 dan skor tertinggi 2,35. Berdasarkan presentase diperoleh presentase terendah $47,06 \%$ dan presentase tertinggi $78,43 \%$. Pada pretest presentase tertinggi adalah sebesar $45,10 \%$, dan meningkat pada posttest hingga $78,43 \%$ dengan Selisih peningkatan sebesar 33,33\%.

Tabel 6.Tabel Profil Posttest Pola Gerak Dasar Kelompok Eksperimen

\begin{tabular}{ccc}
\hline & Pencapaian & $\begin{array}{c}\text { Jumlah Skor } \\
\text { Sempurna }\end{array}$ \\
\hline Jumlah Skor & 1422 & 1904 \\
Rata-rata & 83,65 & 112 \\
Simpangan & 4,92 & 0 \\
Baku & & 100 \\
$\begin{array}{c}\text { Presentase } \\
(\%)\end{array}$ & 74,68 & \\
\hline
\end{tabular}


Tabel 6 diatas menunjukan jumlah skor 1422 dari skor sempurna 1904. Rata-rata skor 83,65 dari rata-rata skor sempurna 112. Sedangkan secara keseluruhan data posttest kemampuan pola gerak dasar pada kelompok eksperimen diperoleh presentase pencapaian sebesar 74,68\%. Berdasarkan presentase, terlihat bahwa pada pretest dengan presentase keseluruhan $60,81 \%$ meningkat hingga $74,68 \%$, selisih peningkatan sebesar $13,87 \%$.

\section{Profil Sikap Empati dan Pola Gerak Dasar Setelah Melalui Penerapan Permainan Konvensional}

Pada pembahasan sebelumnya peneliti telah menampilkan profil data pretest dan posttest pada kelompok eksperimen. Berikut ini peneliti menyajikan profil data posttest atau data setelah perlakuan permainan konvensional pada kelompok kontrol. Profil data tersebut dapat dilihat pada tabel 7 berikut ini:

Tabel 7.Tabel Profil Data Posttest Sikap Empati Kelompok Kontrol

\begin{tabular}{rccccccccc}
\hline Item & IT & IT & IT & IT & IT & IT & IT & IT & Ju \\
Observasi & $\mathbf{1}$ & $\mathbf{2}$ & $\mathbf{3}$ & $\mathbf{4}$ & $\mathbf{5}$ & $\mathbf{6}$ & $\mathbf{7}$ & $\mathbf{8}$ & $\begin{array}{c}\text { mla } \\
\mathbf{h}\end{array}$ \\
& & & & & & & & & 28 \\
Jumlah & 29 & 26 & 31 & 31 & 23 & 26 & 28 & 29 & $\mathbf{2 2 3}$ \\
Rata-rata & 1,7 & 1,5 & 1,8 & 1,8 & 1,3 & 1,5 & 1,6 & 1,7 & $\mathbf{1 3 , 1}$ \\
Si & 0,5 & 0,5 & 0,6 & 0,3 & 0,4 & 0,5 & 0,4 & 0,4 & $\mathbf{1 , 6 2}$ \\
mp & 9 & 1 & 4 & 9 & 9 & 1 & 9 & 7 & \\
ang & & & & & & & & & \\
an & & & & & & & & & \\
Ba & & & & & & & & & \\
ku & & & & & & & & & \\
Presentas & 56, & 50, & 60, & 60, & 45, & 50, & 54, & 56, & $\mathbf{5 4 , 6}$ \\
e (\%) & 86 & 98 & 78 & 78 & 10 & 98 & 90 & 86 & $\mathbf{6}$ \\
\hline
\end{tabular}

Pada Tabel 7 diatas menujukan data posttest sikap empati pada kelompok kontrol atau kelompok yang mendapatkan perlakuan permainan konvensional. Rentan jumlah skor antara 23 sampai 31. Sedangkan rata-rata skor dengan skor terendah 1,35 dan skor tertinggi 1,82. Berdasarkan presentase diperoleh presentase terendah $45,10 \%$ dan presentase tertinggi $60,78 \%$. Pada pretest presentase tertinggi adalah sebesar 52,94\% dan meningkat pada posttest hingga $60,78 \%$ dengan Selisih peningkatan sebesar $7,84 \%$.
Tabel 8.Tabel Profil Posttest Pola Gerak Dasar Kelompok Kontrol

\begin{tabular}{ccc}
\hline & Pencapaian & $\begin{array}{c}\text { Jumlah Skor } \\
\text { Sempurna }\end{array}$ \\
\hline Jumlah Skor & 1355 & 1904 \\
Rata-rata & 79,71 & 112 \\
$\begin{array}{c}\text { Simpangan } \\
\text { Baku }\end{array}$ & 5,3 & 0 \\
$\begin{array}{c}\text { Presentase } \\
(\%)\end{array}$ & 71,2 & 100 \\
\hline
\end{tabular}

Tabel 8diatas menunjukan jumlah skor 1355 dari skor sempurna 1904. Rata-rata skor 79,71 dari rata-rata skor sempurna 112. Sedangkan secara keseluruhan data posttest kemampuan pola gerak dasar pada kelompok kontrol diperoleh presentase pencapaian sebesar 71,2\%. Berdasarkan presentase, terlihat bahwa pada data pretest dengan presentase keseluruhan $60,71 \%$ meningkat hingga $71,2 \%$, selisih peningkatan sebesar $10,49 \%$.

\section{Perbedaan Perkembangan Sikap Empati Dan Pola Gerak Dasar Yang Diajar Melalui Permainan Tradisional Kaulinan Barudak Dan Konvensional}

Secara kasat mata memang kedua kelas tersebut terlihat sama mengalami peningkatan. Namun, jika dilakukan analisis lebih detail terhadap data berdasarkan pengukuran statistik menunjukan bahwa peningkatan kemampuan bersikap empati pada anak usia 5-6 tahun di kelas eksperimen TK Perwari Kota Tasikmalaya lebih unggul dari pada peningkatan kemampuan bersikap empati anak usia 5-6 di kelas kontrol RA IstiqomahKota Tasikmalaya.

Hasil penelitian ini membenarkan (Iswinarti, 2010; Wardani, 2010; dan Gandana, 2015) yang mengemukakan bahwa permainan tradisional dapat memberikan stimulus untuk meningkatkan setiap aspek perkembangan anak usia dini. Kebenaran tersebut dalam penelitian ini secara khusus dikerucutkan terhadap peningkatan kemampuan bersikap empati anak usia 5-6 tahun. Proses pengkerucutan tersebut berlandas pada 
permendikbud no 137 (2014) yang menyatakan bahwa anak usia 5-6 tahun merupakan masa transisi berakhirnya masa pendidikan anak di jenjang pendidikan anak usia dini dan tugas pada titik transisi tersebut perlu mematangkan setiap aspek perkembangannya untuk mempersiapkan pendidikan di jenjang selanjutnya yaitu jenjang sekolah dasar. Berdasarkan hasil pengolahan data skor tes melalui uji N-Gain pada data pretest-posttest kelas eksperimen TK Perwari Kota Tasikmalaya dan data pretest-posttest kelas kontrol RA IstiqomahKota Tasikmalaya, peneliti melakukan uji normalitas terhadap data N-Gain kelas eksperiman dan data N-Gain kelas Kontrol dengan hasil masing-masing data $\mathrm{N}$-Gain berdistribusi normal. Berhubung kedua data N-Gain masing kelas tersebut berdistribusi normal, maka peneliti melakukan uji perbedaan dengan uji $t \quad 2$ sampel independen (statistik parametrik) dengan hasil nilai sig $=0,000<a(0,05)$ yang artinya terdapat perbedaan yang signifikan antara peningkatan kemampuan bersikap empati anak usia 5-6 tahun di TK Perwari Kota Tasikmalaya dengan peningkatan kemampuan bersikap empati anak usia 5-6 tahun di RA IstiqomahKota Tasikmalaya.

Selain pada variabel kemampuan bersikap empati pada anak usia 5-6 tahun, perlakuan yang diberikan juga memberikan pengaruh positif bagi variabel kemampuan pola gerak dasar anak usia 5-6 tahun di TK Perwari Kota Tasikmalaya dan RA IstiqomahKota Tasikmalaya. Serupa dengan variabel kemampuan bersikap empati, pada variabel kemampuan pola gerak dasar juga secara kasat mata tidak terlihat perbedaan pengaruh antara kelompok yang menggunakan permainan tradisional dengan kelompok yang menggunakan permainan konvensional. Aka tetapi setelah dilakukan pengolahan dan analisis data lebih lanjut lagi melalui uji $\mathrm{N}$ Gain antara kedua kelompok sampel menunjukan nilai sig $=0,012<\mathrm{a}(0,05)$ yang artinya terdapat perbedaan peningkatan kemampuan pola gerak dasar pada anak usia dini antara kelompok eksperimen dengan penerapan permainan tradisional kaulinan barudak dan kelompok kontrol dengan penerapan permainan konvensional. Dimana berdasarkan peningkatan skor kelompok eksperimen dengan penerapan permainan tradisional kaulinan barudak menunjukan pengaruh atau peningkatan skor yang lebih baik.

Permainan tradisional "kaulinan barudak" yang diterapkan dalam proses pengembangan kemampuan pola gerak dasar anak usia dini adalah seperti permainan Sondah, Congkak, Loncat tinggi, Balap kelereng dalam sendok, Memasukan pensil pada lubang botol, Egrang Batok dan Dam-Daman. Permainan-permainan tersebut dapat dijadikan salah satu alternatif bentuk pembelajaran. Iswinarti (2010) mengemukakan bahwa "Terkait permainan tradisional "kaulinan barudak" dapat mengembangkan setiap aspek perkembangan anak, maka dapat diambil kesimpulan bahwa permainan tradisional dapat dijadikan media kegiatan belajar anak." Permainan tradisional memberikan kesempatan kepada anak untuk dapat mengembangkan berbagai aspek perkembangan anak.

Seperti pernyataan Iswinarti (2010) yang menyatakan bahwa "Permainan tradisional cenderung lebih menekankan pada proses perkembangan kognitif, motorik kasar, motorik halus, sosial, emosional, dan bahasa anak. selain itu, permainan tradisional dapat mendidik anak melalui aturan-aturan yang telah disepakati bersama." Permainan tradisional mendukung anak untuk mengembangkan kemampuan kognitif, motorik kasar dan motorik halus. Permainan ini membuat anak secara tidak sadar melatih kemampuan gerak dasarnya. Seperti pada permainan sondah, egrang batok dan balap kelereng merupakan bentuk permainan tradisional yang melatih keseimbangan anak. Selain itu dalam permainan tersebut juga anak harus berusaha untuk tetap fokus pada tujuan atau sasaran. Permainan tradisional yang diterapkan pada pembelajaran untuk anak usia 5-6 tahun merupakan bentuk pembelajaran aktif. Natawijaya dalam Nikmah (2012: hlm 6) menjelaskan bahwa "Belajar aktif merupakan suatu proses kegiatan pembelajaran yang 
cenderung lebih mengedepankan keaktifan anak didik dalam aspek "fisik, mental intelektual, dan emosional" untuk mencapai tujuan pembelajaran berdasarkan hubungan "antara aspek kognitif, afektif, dan psikomotor." Pembelajaran aktif untuk anak usia 5-6 tahun sangatlah peting guna menunjang perkembangan kemampuan pola gerak dasar anak. Perkembangan kemampuan pola gerak dasar akan memberikan pengaruh yang besar bagi setiap aktivitas anak pada masa mendatang.

\section{KESIMPULAN DAN SARAN}

Berdasarakan hasil pengolahan dan analisis data yang telah dilakukan, dapat ditarik kesimpulan sebagai berikut: 1) Profil kemampuan bersikap empati dan pola gerak dasar anak usia 5-6 tahun di TK Perwari Kota Tasikmalaya dan RA Istiqomah Kota Tasikmalaya masuk kedalam kategori "Muncul", dapat diartikan rata-rata sikap empati dan pola gerak pada anak usia 5-6 tahun pada kelompok kontrol dan eksperimen hanya baru terlihat beberapa kali saja, atau belum sering terlihat dilakukan oleh anak; 2) Program kegiatan pembelajaran dengan melakukan penerapan permainan tradisional "kaulinan barudak" Anak terlihat anak lebih memperhatikan temannya yang sedang berbicara atau berpendapat, selain itu juga anak berinisiatif dan mau untuk mengambilkan barang untuk orang laindan dari segi pola gerak dasar sebagian besar anak terlihat lebih baik dalam hal berjalan maju atau mundur sambil memegang suatu benda, dan juga anak terlihat lebih mampu untuk berjalan dan atau berlari keberbagai arah (zig-zag) sambil memegang benda; 3) Program kegiatan pembelajaran dengan permainan konvensional pada kelas kontrol anak-anak dapat menunjukan perkembangan yang cukup baik dalam sikap empati dan pola gerak dasar. Penerapan permainan konvensional juga menunjukan dampak yang positif bagi perkembangan anak; 4) kemampuan pola gerak dasar pada kelompok eksperimen diperoleh presentase pencapaian sebesar $74,68 \%$; 5)
Profil Sikap Empati dan Pola Gerak Dasar Setelah Melalui Penerapan Permainan Konvensional bahwa data posttest kemampuan pola gerak dasar pada kelompok kontrol diperoleh presentase pencapaian sebesar $71,2 \%$; 6) Terdapat perbedaan yang signifikan antara sikap empati dan pola gerak dasar di kelompok kontrol dan eksperimen.

\section{PUSTAKA RUJUKAN}

Beaty, J. J. (1994). Observing Development of the Young Child. Engglewood Cliffs, New Jersey: Prentice Hall, Inc.

Creswell, J. W. (2010). Research Design; Pendekatan Kualitatif, Kuantitatif, dan Mixed. Terjemahan Achmad Fawaid, et.al. Jogjakarta: Pustaka Pelajar.

David, W.J. (2009). Handedness and Early Chilhood Development. Demography. 2009 May; 46 (2), 281-301.

Gandana, G. (2015). Meningkatkan Kecerdasan Emosional Anak Usia Dini melalui Permainan Tradisional "Kaulinan Barudak". Tesis: SPs Universitas Pendidikan Indonesia.

Geldard, K. \& Geldard, D. (2012). Konseling Anak-Anak. Jakarta: Indeks.

Ioannidou, F. \& Konstantikaki, V. (2008). Emphaty and Emotional Intelligence: What is it Really About?: International Journal of Caring Sciences, 1 (3), 118-123.

Iswinarti. (2010). Nilai-Nilai Terapeutik Permainan Tradisional Engklek Untuk Anak Usia Sekolah Dasar. Naskah Publikasi Penelitian Dasar Keilmuan. Fakultas Psikologi: Universitas Muhammadiyah Malang: Malang.

Mahendra, A. (2007). Teori Belajar Mengajar Motorik. Bandung: FPOK UPI.

Nikmah, S. (2012). Penggunaan Metode Permainan dalam Pembelajaran IPA untuk Meningkatkan Aktivitas dan Hasil Belajar Siswa Kelas IV Sekolah Dasar Negeri 11 Sungai Melayu Rayak: Artikel Penelitian. Fakultas Keguruan dan Ilmu Pendidikan. Universitas Tanjungpura: Pontianak. 
Mashar, R. (2011). Emosi Anak Usia Dini dan Strategi Pengembangannya. Jakarta: Kencana.

Sudaryanti. (2012). Pentingnya Pendidikan Karakter Anak Usia Dini. Jurnal Pendidikan Anak, 1 (1), 11-20.

Sugiyono. (2012). Metode Penelitian Kualitatif, Kuantitatif, dan $R$ and $D$. Bandung: Alfabeta.

Sujanto, dkk. (2009). Psikologi Kepribadian. Jakarta: Bumi Aksara. 